\title{
A novel approach for assessing watershed susceptibility using weighted overlay and analytical hierarchy process (AHP) methodology: a case study in Eagle Creek Watershed, USA
}

\author{
Fadhil K. Jabbar ${ }^{1,2}$ (D) $\cdot$ Katherine Grote $^{1} \cdot$ Robert E. Tucker $^{1}$ \\ Received: 28 January 2019 / Accepted: 29 August 2019 / Published online: 6 September 2019 \\ (C) The Author(s) 2019
}

\begin{abstract}
Watershed vulnerability and the characterization of potential risk are important inputs for decision support tools in assessing watershed health. Most previous studies have focused on the assessment of the environmental risk using physicochemical properties of surface water and mathematical models to predict the health of a watershed. Here, we present a new methodology for evaluating watershed vulnerability using the analytic hierarchy process (AHP) and weighted overlay analysis. The new methodology provides an inexpensive approach for assessing areas that need more investigation based on known factors such hydrogeological, geological, and climate parameters without the need for site-specific physicochemical data. The proposed method was implemented using six main factors that influence water quality: land use, soil type, precipitation, slope, depth to groundwater, and bedrock type. Vulnerability was predicted for ten sub-watersheds within the Eagle Creek Watershed in Indiana using publicly available data input into geographic information system. Combination of watershed susceptibility assessment and GIS spatial analysis tools was used to produce the maps that show the susceptible zones within a watershed. A comparison of the resulting vulnerability estimates showed the expected significant positive correlations with measurements of nitrate, phosphate, temperature, and electrical conductivity. Likewise, the vulnerability estimates negatively correlated with dissolved oxygen and E. coli. Furthermore, the validation of the proposed approach revealed that the areas predicted to have high vulnerability did have lower water quality indices; the results showed a high negative correlation $\left(r^{2}=0.77, p<0.05\right)$ between water quality index (WQI) and vulnerability which strongly suggests this method can be used successfully to assess a watershed's susceptibility.
\end{abstract}

Keywords Susceptibility · Watershed health assessment · Analytic hierarchy process · Eagle Creek Watershed $\cdot$ Land uses · Weighted overlay analysis

\section{Introduction}

Water quality degradation from multiple sources of contamination has become a critical global issue (USEPA 2016; FAO 2017). Many water bodies across the USA are classified as impaired. Studies show that about $85 \%$ of streams and rivers and $80 \%$ of lakes and reservoirs are affected by nonpoint

Responsible editor: Marcus Schulz

Fadhil K. Jabbar

fkj5gd@mst.edu

1 Department of Geosciences and Geological and Petroleum Engineering, Missouri University of Science and Technology, McNutt Hall, 1400 N. Bishop Ave, Rolla, MO 65401, USA

2 College of Science, University of Misan, Amarah, Iraq source (NPS) pollution (USEPA 2016), which can be attributed to sources such as agriculture and urbanization (Rowny and Stewart 2012; Liu et al. 2014; Ji et al. 2017). Agriculture can cause water quality degradation due to excess nutrients through fertilizers and manure (Kourgialas et al. 2017; Jabbar and Grote 2019) and runoff from pesticides and herbicides (Cruzeiro et al. 2015), as well as increasing turbidity level due to sedimentation and soil erosion (Zhang and Huang 2014). Numerous studies recorded the negative impacts of some agricultural practices on water quality (Dupas et al. 2015; Fournier et al. 2017). Likewise, urbanization affects the water quality through sediment, oils, and solid wastes washed from hard surfaces, bacteria, and input of nutrients from failing septic systems and wastewater (USEPA 2008; Walters et al. 2011; Zhao et al. 2015; Strangway et al. 2017).

Assessment of watershed susceptibility to contamination is an important step for decision making for sustainable 
environmental protection. As well as anthropogenic inputs, some features of the landscape or geologic conditions may make the watersheds more vulnerable to degradation. The vulnerability can be described as the level to which a system or system components are presumed to be impaired due to exposure to a potential risk or stress. Quantifying the vulnerability of watersheds to NPS pollution is important for recognizing which watersheds are most at risk of impairment and determining where changes in land use/land cover (LULC) might improve water quality conditions (USEPA 2008). Changes in land use, along with soil attributes, combined with topography, climate, hydrology, and other landscape variables are the most important factors contributing to a watershed's quality (Bansal et al. 2014; Neupane and Kumar 2015; Fan and Shibata 2015; Serpa et al. 2017), so the watershed vulnerability assessment should be adaptable to potential changes. Hydrologists and environmental scientists are becoming increasingly aware and focused on the importance of identifying and quantifying risks to evaluate watershed's health by using a convenient statistical technique and risk indicators. Therefore, the use of an appropriate model for watershed assessment that includes the variables listed above and can be modified as these variables change could be essential for evaluating continuous spatial and temporal distribution variations in watershed information. Some of these models are discussed in the following paragraph.

A number of methods have been developed to assess a watershed's susceptibility to contamination using integrated watershed models and criteria evaluation methods (Sahoo et al. 2016; Ahn and Kim 2017; Kanakoudis et al. 2017). For example, the method for vulnerability mapping conducted by Tran et al. (2012) used the self-/peer-appraisal method and 50 variables collected by the US Environmental Protection Agency's (EPA) Regional Vulnerability Program for 141 watersheds to map watershed vulnerability in the Northeast of the USA. In another study, geostatistical applications were used to assess the vulnerability of watersheds to chloride contamination in urban streams for seven sites within four watersheds in the Greater Toronto area (Betts et al. 2014). Simha et al. (2017) applied vulnerability assessment as a quantitative technique in the island of Lesvos in Greece, where a set of 25 indicators was used to identify the influence of strategic management on the vulnerability indices. Moreover, the US EPA has developed different approaches and tools to assess watershed susceptibility to surface water pollution. One of the best known of these tools is the WRASTIC method, which is based on seven parameters that affect the potential for pollution including presence of wastewater $(W)$, recreational activities $(R)$, agricultural activities $(A)$, size of the watershed $(S)$, transportation avenues $(T)$, industrial activities $(I)$, and the amount of vegetative ground cover (C) (USEPA 2000).

Modern geographical information system (GIS) tools are a powerful method for gathering, managing, and manipulating spatial analysis data. In addition, GIS can provide a more consistent environment for displaying the input datasets and the results have achieved by a model, which is more useful in a decision-making process. The external models which linked to GIS data provide a manageable way for combining and evaluating parameters such as slope, land use/land cover, and soil types (Wondrade et al. 2013; Yu et al. 2016).

One method of evaluating natural systems such as watersheds is to use multiple-criteria decision-making (MCDM) techniques. One of the most widely used MCDM techniques is the analytic hierarchy process (AHP) (Saaty 1980). This approach has many steps, including assigning the hierarchical structure, specifying and ranking the relative weights for both the criteria and sub-criteria, determining the weights of each substitute, and measuring the final score (Saaty 2008; Moeinaddini et al. 2010). Using GIS and AHP has been proven effective in analyzing natural hazards such as landslides and floods (Gamper et al. 2006; Fernández and Lutz 2010) and environmental studies (Ying et al. 2007; Rahman et al. 2014). The GIS-based and analytic hierarchy process has been applied by Koc-San et al. (2013) to choose a suitable site for an astronomical observatory. The same technique was used in Konya, Turkey, by Uyan (2013) to select the best site for solar farms. Likewise, Anane et al. (2012) applied this approach in the Nabeul-Hammamet region (Tunisia) to find suitable sites for irrigation with reclaimed water. Dong et al. (2013) used remote sensing, GIS, and AHP models to assess a habitat suitable for water birds in the West Songnen Plain in China.

In this research, we propose a new watershed susceptibility assessment method to evaluate watershed susceptibility to pollution using GIS and AHP methods. Six main factors have suggested in this study, which include land use/land cover, soil type, average annual precipitation, slope, depth to groundwater, and bedrock type. The general assumptions that were considered in this study of watershed vulnerability assessment are based on the response of watersheds to different contamination impacts and how the six factors work together to affect watershed health. This approach uses different databases to predict the NPS pollution in a watershed without field and lab work, which is a useful first approximation of vulnerability with minimal cost and time commitments.

\section{Study area}

The Eagle Creek Watershed (ECW) is located in Central Indiana. The watershed is in the northern portion of the Upper White River Watershed that lies within the Mississippi River Basin (Fig. 1) and is a hydrologic unit code 14 (HUC14) level watershed. The drainage area is about $459 \mathrm{~km}^{2}$, and there are 10 sub-watersheds within the ECW varying in size from 26.9 to $70.7 \mathrm{~km}^{2}$ (Table 1). The ECW includes three main branches: School branch, Fishback Creek, 
Fig. 1 The location of the Eagle Creek Watershed

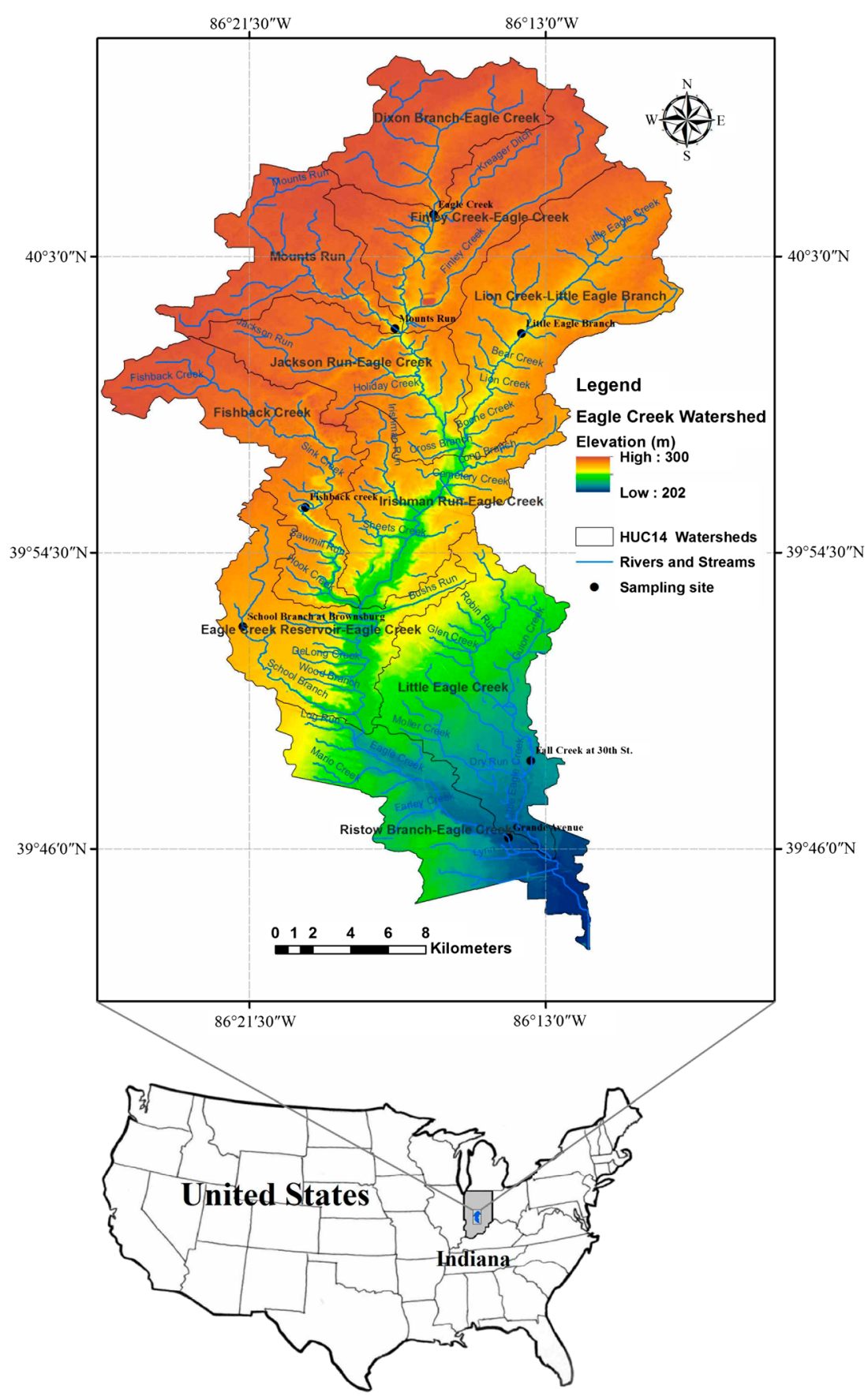

and Eagle Creek branch, which flow into the Eagle Creek Reservoir. The Eagle Creek Reservoir is the main source of drinking water for Indianapolis. These branches are fed by eight main tributaries: Dixon Branch, Finley Creek, Kreager Ditch, Mounts Run, Jackson Run, Woodruff Branch, Little Eagle Branch, and Long Branch. The average flow distribution for the three major branches is around $2.85 \mathrm{~m}^{3} / \mathrm{s}$ for Eagle Creek and contributing about $80 \%$ of the water to the reservoir, while the average flow distributions for both Fishback Creek and School Branch are $1.1 \mathrm{~m}^{3} / \mathrm{s}$ and $0.5 \mathrm{~m}^{3} / \mathrm{s}$, respectively, which contributes about $20 \%$ of water to the reservoir (Tedesco et al. 2005).

The primary land use in the ECW is agriculture with approximately $56 \%$, and $38 \%$ of the watersheds covered with urban land use, mostly in the southeast part of the watershed. The substantial majority of the remaining is either forested land or is grassland (USGS, National Hydrography Dataset). Precipitation is characterized by long-duration and moderateintensity storms during the cooler months, and short-duration, high-intensity storms in the late spring and summer months. 
Table 1 Sub-watersheds and their drainage area in the Eagle Creek Watershed

\begin{tabular}{llll}
\hline Sub-watershed name & River or stream & Station name & Drainage area $\left(\mathrm{km}^{2}\right)$ \\
\hline Dixon Branch-Eagle Creek & Eagle Creek & Eagle Creek & 42.5 \\
Mounts Run & Mounts Run & Mounts Run & 41.2 \\
Finley Creek-Eagle Creek & Finley Creek & Finley Creek & 26.9 \\
Lion Creek-Little Eagle Branch & Little Eagle Branch & Little Eagle Branch & 40.6 \\
Jackson Run-Eagle Creek & Jackson Run & Fishback Creek & 48.5 \\
Fishback Creek & Fishback Creek & & 54.0 \\
Irishman Run-Eagle Creek & Irishman Run & School Branch at Brownsburg & 48.5 \\
Eagle Creek Reservoir-Eagle Creek & School Branch & Fall Creek at 30th St. & 51.0 \\
Little Eagle Creek & Little Eagle Creek & Grande Avenue & 70.7 \\
Ristow Branch-Eagle Creek & Eagle Creek & & 35.1 \\
\hline
\end{tabular}

The average annual precipitation for the Eagle Creek Watershed is $1050 \mathrm{~mm}$ (Tedesco et al. 2005). According to the Midwestern Regional Climate Center (MRCC 2016), the lowest rainfall occurs in February, with an average of $59.7 \mathrm{~mm}$ and the highest rainfall occurs in May with an average of $115.5 \mathrm{~mm}$. The watershed topography is relatively flat, with slopes less than $3 \%$, especially in the agricultural areas. Steeper slopes are found adjacent to rivers and streams. Soils in the upper portion of the watershed consist of thin loess over loamy glacial till. These soils are classified as deep and poorly drained, but in the northwest part of the watershed, soils are poorly drained to well drained, while downstream areas are dominated by soils that are generally classified as deep and well drained to slightly poorly drained; soils were formed in a thin layer of silt and resulting from underlying glacial till (Hall 1999). The bedrock units of the Eagle Creek Watershed are generally characterized by brown, fine-grained dolomite and dolomitic limestone in the far northeastern part of the watershed, and sandy dolomitic limestone to brown sandy dolomite, but the southwest part is characterized by the gray, shaley fossiliferous limestone. The southern part of the watershed is dominated by brownish-black shale, greenish-gray shale, in addition to small amounts of dolomite and dolomitic quartz sandstone (Shaver et al. 1986; Gray et al. 1987).

\section{Materials and methods}

\section{GIS data processing}

Remote sensing data were used to create thematic maps for the proposed study area (Fig. 2). The general topographic surveying and mapping of the landscape features within the ECW were derived from a digital elevation model (DEM) has resolution $(30 \mathrm{~m})$ to investigate the important watershed characteristics, such as elevation variations and the slope of the land surface. The National Hydrography Dataset (NHD) and Watershed Boundary Dataset (WBD), which are managed by the USGS, were applied to calculate some watershed characteristics such as soil type, depth to groundwater, bedrock type, hydrologic units, catchment areas, and related features, including rivers and streams (USGS 2016). The National Land Cover Database 2011 (Homer 2015), which includes 15 LULC categories, was used for this study. Some of the LULC categories were combined to be more meaningful in this study. All categories labeled "developed" were aggregated into one class "urban", and all categories labeled "forest" were aggregated into one class. Similarly, "wetland" categories were aggregated. GIS-based methods were applied to analyze the datasets and to determine the average values of parameters for each sub-watershed. The Parameter-elevation Regressions on Independent Slopes Model (PRISM) has been adopted to derive the average annual precipitation raster for the climatological data period 1961-1990 (Daly 1996).

\section{Water quality data}

A statistical description of the water quality parameters which were measured by the Indiana Department of Environmental Management, Indiana Water Quality Atlas, (https://www.in. gov/idem/nps/pages/iwqa/index.html) is shown in Fig. 3. This figure shows that significant differences in water quality measurements occurred between sub-watersheds. Samples were collected from eight river stations which were treated as independent watersheds. Temperature and $\mathrm{pH}$ showed relatively little variation and are the most constant parameters within the study area. Dissolved oxygen (DO) showed a relatively slight variation for many sub-watersheds but was significantly higher in the Eagle Creek River at the Grande Avenue, School Branch, and Fall Creek stations. Electrical conductivity (EC) showed more significant variation between watersheds where the minimum value was observed between 160 and $640 \mu \mathrm{s} / \mathrm{cm}$ and the maximum value was between 523 and $1405 \mu \mathrm{s} / \mathrm{cm}$. Results of turbidity reveal relatively little differences between all sub-watersheds, except the highest turbidity value was observed in the School Branch watershed (about 90 


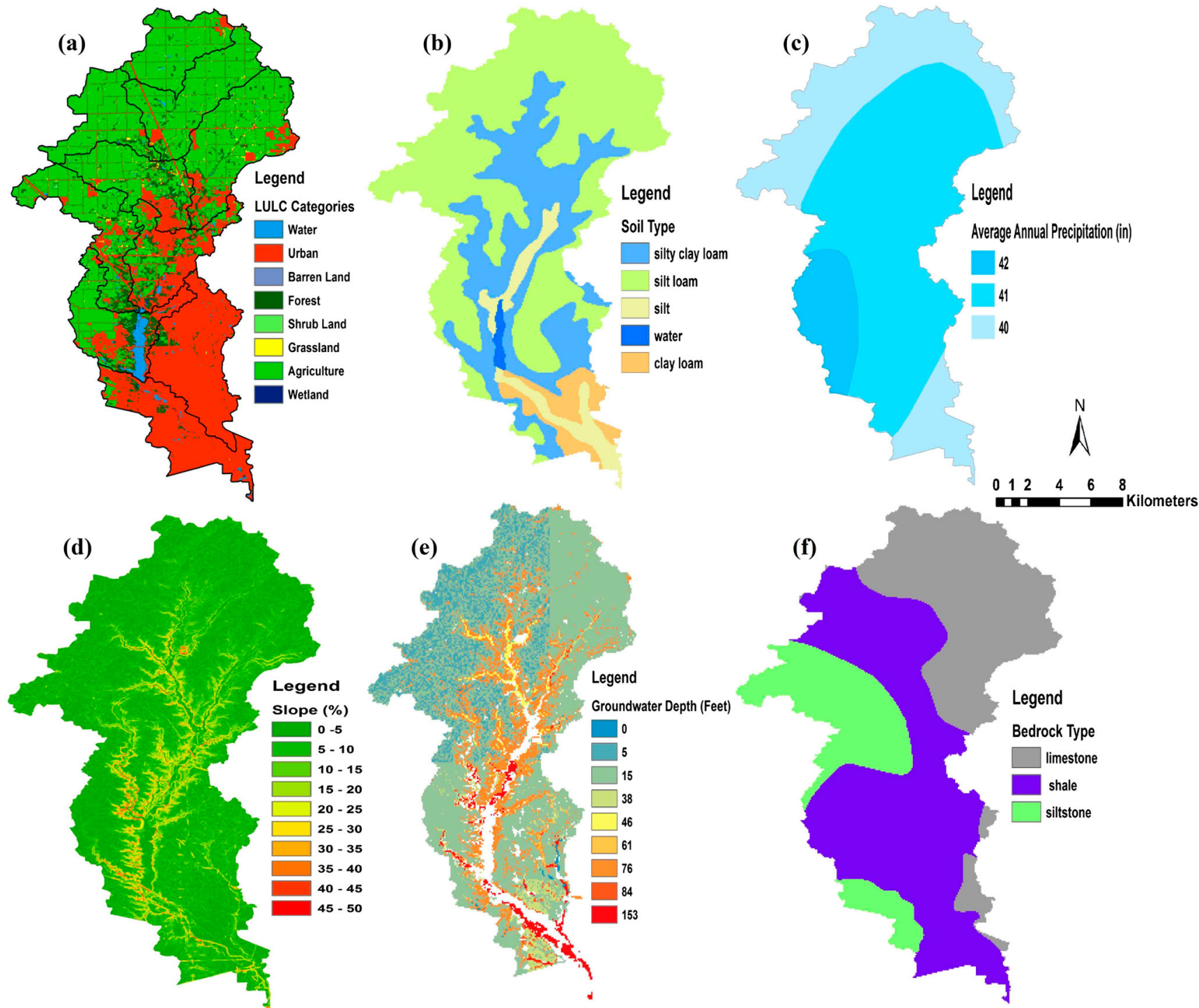

Fig. 2 Thematic maps of the layers proposed for watershed susceptibility assessment method

NTU). The measurements of Escherichia coli (E. coli), phosphate, and nitrate showed significant differences between subwatersheds, where $E$. coli was somewhat higher in the southern part of the study area. Phosphate and nitrate concentrations are comparatively higher in northern sub-watersheds, where agricultural land is the most dominant land use.

\section{Methodology of watershed susceptibility assessment}

\section{Analytical hierarchy process evaluation model}

The AHP is an effective multicriteria decision-making tool that can be used to set a systematic approach for evaluating and integrating the impacts of different factors, which include some levels for qualitative and quantitative information (Saaty 1990). The
AHP method can reduce problems between factors such as interrelationship and overlapping. The relative weight for each factor considered in this study was estimated using the methods of AHP and pairwise comparison matrix. The comparative scale (Saaty 1980 ) is a common methodology typically performed to analyze the comparison between various factors. The relative importance is measured between two factors based on a scale from 1 to 9 , where 1 indicates the two factors are equally important while 9 reflects that one factor is much more important than another (Table 2). The consistency ratio (CR) was computed to check the differences between the pairwise comparisons and the reliability of the measured weights. The consistency ratio should be $<0.1$ to be accepted; otherwise, it is important to check subjective judgments and recalculate the weights (Saaty and Vargas 2001).

In current research, the decision-making problem structure was created and includes numbers that are symbolized by $m$ and $n$. The values for both $a_{i j}(i=1,2,3 \ldots, m)$ and $(j=1,2$, 

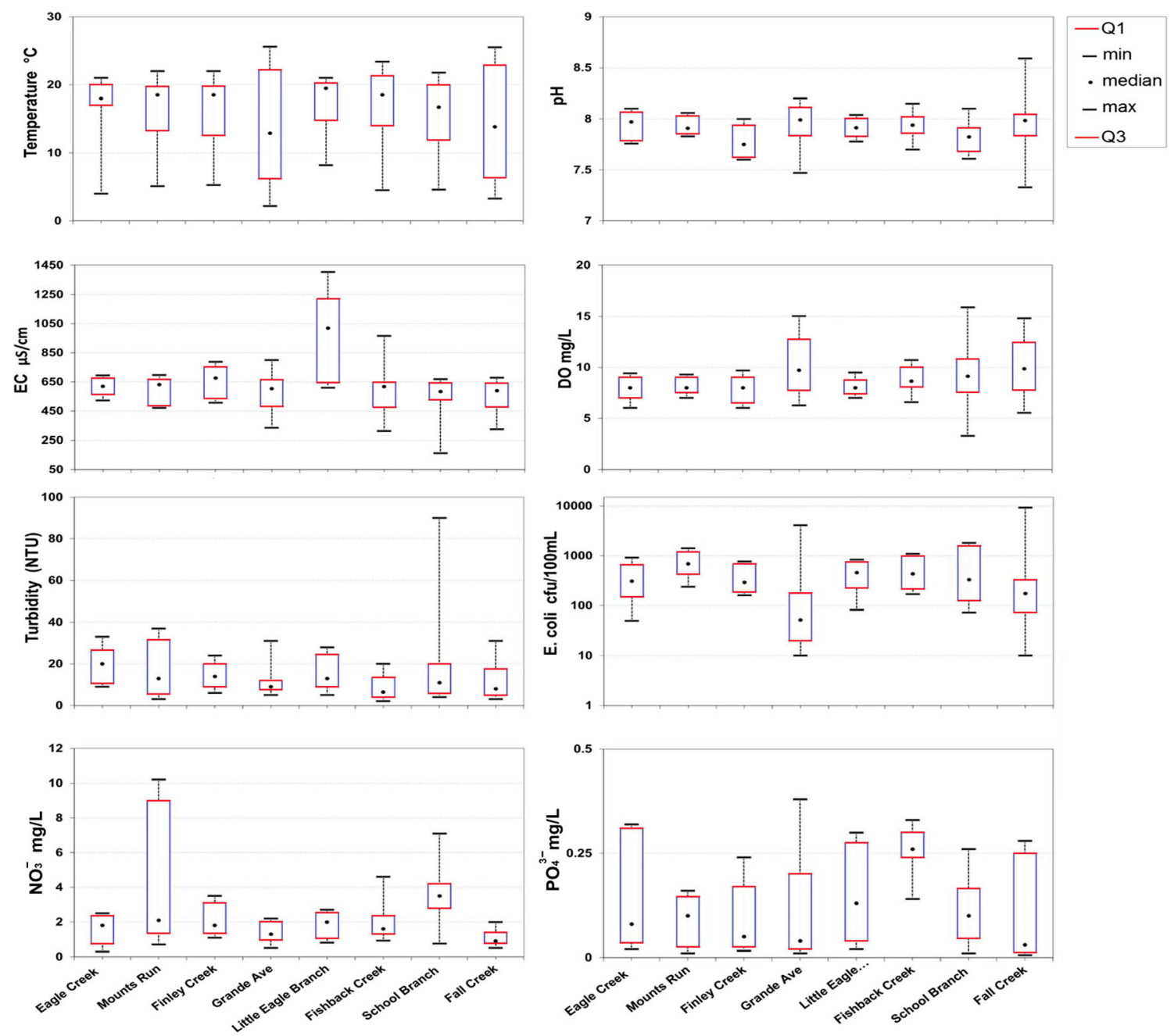

Fig. 3 Boxplots showing the range of variations from minimum to maximum and the typical value (median) of water quality parameters

$3 . ., n)$ are applied to find the performance values of matrix of $i$ th and $j$ th. The values of comparison criteria are utilized to fill out the upper diagonal of the matrix, while the lower triangular of the matrix is filled with the reciprocal values of the upper diagonal. In pairwise comparison matrix $A$, the element $a_{i j}$ of the matrix is identified as the relative importance of the alternatives $i$ th and $j$ th with consideration to criterion $A$ as shown below where $a_{j i}$ is the reciprocal values of $a_{i j}$.

Table 2 Judgments scale and definitions for the pairwise comparison

\begin{tabular}{llc}
\hline Qualitative definition & Explanation & Intensity of importance \\
\hline Equal importance & Two activities contribute equally to the objective & 1 \\
Weak & Experience and judgments slightly favor one activity over another & 3 \\
Moderate importance & & 4 \\
Moderate plus & Experience and judgment strongly favor one activity over another & 5 \\
Strong importance & & 6 \\
Strong plus & An activity is favored very strongly over another and dominance & 7 \\
Very strong or demonstrated importance & is demonstrated in practice & 8 \\
Very, very strong & The evidence favoring one activity over another is of the highest & 9 \\
Extreme importance & possible order of affirmation &
\end{tabular}


The comparison matrix for any problem can be represented by the following decision matrix:

$A=\left(\begin{array}{cccc}1 & a_{12} & \cdots & a_{1 n} \\ 1 / a_{12} & 1 & a_{23} & a_{2 n} \\ \cdots & 1 / a_{23} & \cdots & \cdots \\ 1 / a_{1 n} & 1 / a_{2 n} & \cdots & 1\end{array}\right)$

where $a_{j} ; I, j=1,2, \ldots \ldots, n$ is the element of row $i$ and column $j$ of the matrix and equal to the number of alternatives.

The eigenvector was calculated for each row by using Eq. (2):

$E g_{i}=\sqrt[n]{a_{11} \times a_{12} \times a_{13} \times \cdots \times a_{1 n}}$

where, $E g_{i}=$ eigenvector for the row $i ; n=$ number of elements in row $i$.

The priority vector $\left(P r_{i}\right)$ was identified by normalizing the eigenvalues to 1 using the equation below:

$\operatorname{Pr}_{i}=E g_{i} /\left(\sum_{k=1}^{n} E g_{k}\right)$

The lambda max $\left(\lambda_{\max }\right)$ can be calculated from the summation of the results of multiplication of the priority vector and the summation of the column of the inverse matrix as shown below:

$\lambda_{\max }=\sum_{j=1}^{n}\left(W_{j} \times \sum_{i=1}^{m} a_{i j}\right)$

where $a_{i j}=$ the sum of criteria in each column; $W i=$ the value of assigned weights for each criterion that is compatible with the priority vector in the decision matrix, where the values $i=1,2, \ldots m$, and $j=1,2, \ldots n$.

The consistency ratio (CR) was calculated by using the following equation:

$\mathrm{CR}=\frac{\mathrm{CI}}{\mathrm{RI}}$

where CI is the consistency index can be determined according to the equation:

$C I=\frac{\lambda_{\max }-n}{n-1}$

where $n$ is the size of the matrix.

RI represents the random index that refers to the consistency of the pairwise comparison matrix which is randomly generated. It is obtained as the average of the random consistency index, which was computed by Saaty (1980) using a sample of 500 matrixes randomly generated. In the current study, weight scores for factors are obtained based on the AHP model (Table 3). A similar approach was applied to obtain rating values for individual sub-criteria used for watershed susceptibility assessment.

To calculate the watershed susceptibility values of the study area, the weighted overlay analysis was applied based on the following equation:

$\mathrm{WS}=\sum_{j=1}^{n} W_{j} \times C_{i j}$

where WS is the watershed susceptibility for area $i, W_{j}$ is the relative importance weight of criterion, $C_{i j}$ is the grading value of area $i$ under criterion $j$, and $n$ is the total number of criteria.

In this study, the assessment of a watershed's susceptibility was the main objective for using the decision hierarchy. The process of hierarchy structure in the decision problem involves two steps. The first step has been classified into six factors: land use, soil type, precipitation, slope, depth to groundwater, and bedrock type. The second step includes 46 sub-categories used to evaluate the watershed's health. For this study, according to the judgment of experts and literature reviews in this field (Eimers et al. 2000; Lopez et al. 2008; Xiaodan et al. 2010; Furniss et al. 2013; USEPA 2013; Shao et al. 2016; Siqueira et al. 2017), in addition to the data available and required for the study area, each factor was categorized into classes (sub-category). Then, each sub-category was specified for a suitability rating value. After creating these factors, the maps which are required for each layer were obtained as a shapefile (vector) or raster. Shapefile maps were then converted to raster maps to be more useful in reclassifying sub-categories based on the new rating, as illustrated in (Fig. 4). To prepare each category and sub-category, a number of steps were implemented using ArcGIS 10.5 software (i.e., overlay, convert, reclassify, and raster calculator). Output watershed susceptibility map is carried out by calculating the weighted overlay of the land uses/land cover, soil type, average annual precipitation, slope, depth to groundwater, and bedrock type.

\section{Factors used for watershed susceptibility assessment}

To assess the watershed susceptibility to pollution, six main factors have been used in this study: land use, soil type, average annual precipitation, slope, depth to groundwater, and bedrock type. The determination of factors, the development of ratings for each, and the ranking of the weights were based on a synthesis of previous studies which were conducted to investigate possible factors and their impacts on the surface water quality (Eimers et al. 2000; Lopez et al. 2008; Xiaodan et al. 2010; Furniss et al. 2013; USEPA 2013; Shao et al. 2016; Siqueira et al. 2017) as well as evaluation of factors correlating with environmental degradation in similar Midwestern watersheds (Hoorman et al. 2008; Jabbar and Grote 2019). Virtually, all of these factors have been demonstrated to 
Table 3 A pairwise comparison matrix developed for assessing the relative importance of criteria for watershed susceptibility assessment

\begin{tabular}{llllllll}
\hline Factor & LULC & ST & BRT & Slope & AAP & DTG & Weights \\
\hline LULC & 1 & 3 & 4 & 5 & 3 & 2 & 0.36 \\
Soil type (ST) & 0.33 & 1 & 5 & 3 & 2 & 2 & 0.22 \\
Bedrock type (BRT) & 0.25 & 0.2 & 1 & 0.33 & 0.33 & 0.5 & 0.05 \\
Slope & 0.2 & 0.33 & 3 & 1 & 0.33 & 1 & 0.10 \\
Average annual precipitation (AAP) & 0.33 & 0.5 & 3 & 3 & 1 & 3 & 0.18 \\
Depth to groundwater (DTG) & 0.5 & 0.5 & 2 & 1 & 0.33 & 1 & 0.09 \\
CR value = 0.02 & & & & & & & \\
\hline
\end{tabular}

impact surface water quality and change essential chemical properties of the water within the watershed. The general assumptions were considered in the study of watershed vulnerability based on the response of a watershed systematically to different contamination impacts and how the six factors working together can affect the watershed's health.
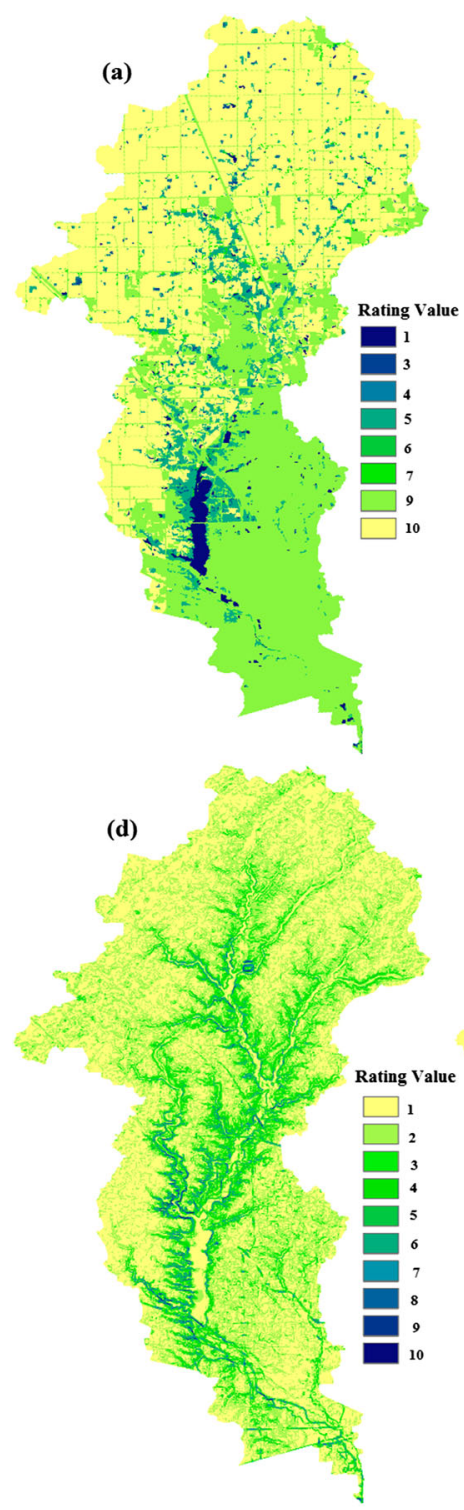
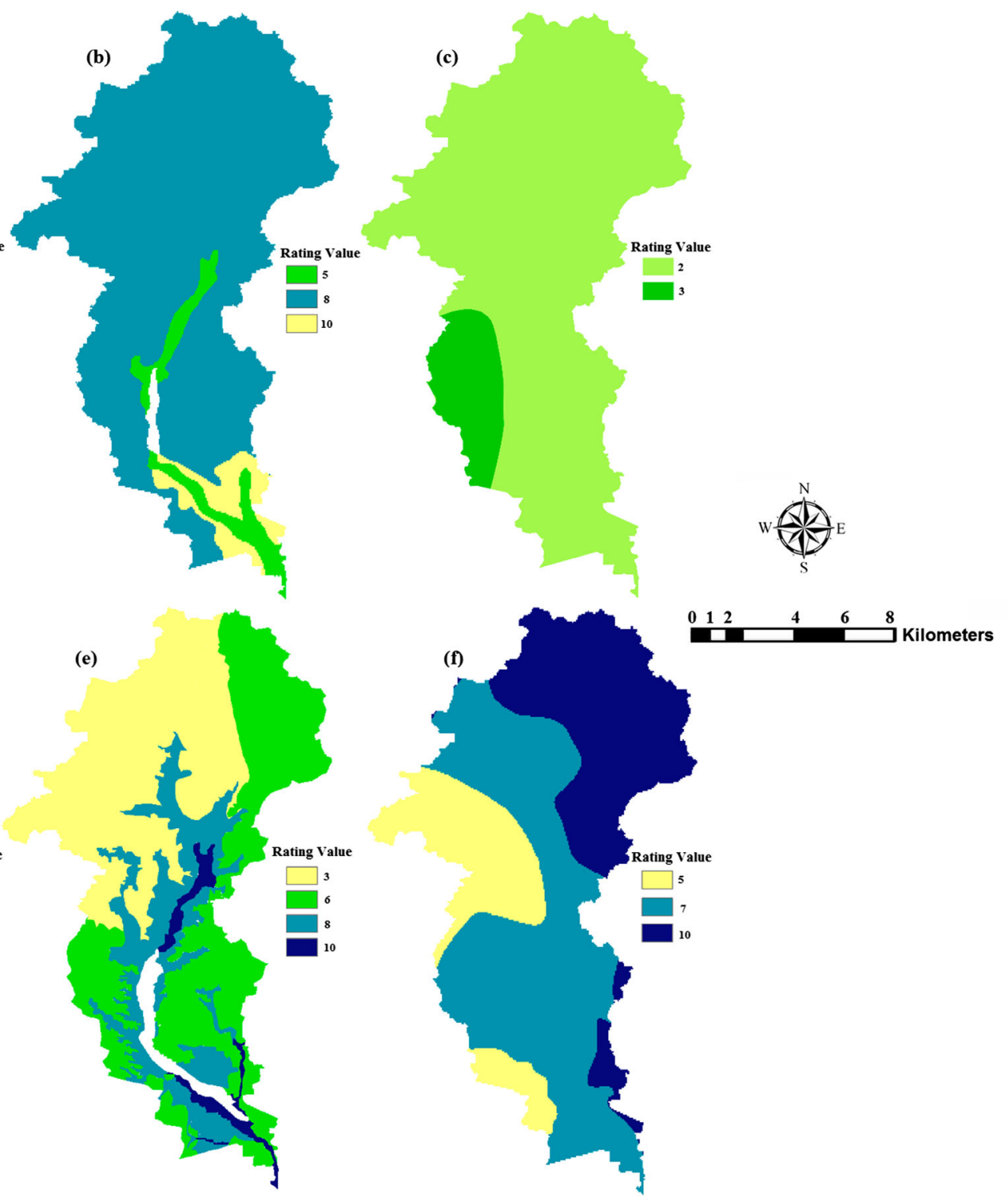

Figure 4

Fig. 4 Thematic maps of the layers after rating for (a) land use/land cover, (b) average annual precipitation, (c) soil type, (d) slope\%, (e) depth to groundwater, and (f) bedrock type 
For each of the factors discussed below, the boundaries of each sub-watershed were determined using the Watershed Boundary Dataset, maintained by the USGS. These boundaries were used for further GIS-based analysis on different data sets. The origins of each data set and manipulations of these data sets to obtain the desired parameters are described below.

\section{Land use/land cover}

Watershed health is susceptible to LULC. Therefore, LULC has been regarded as one of the most important factors having an effect on water quality (Mouri et al. 2011; Yu et al. 2016; Ding et al. 2016). LULC can impact surface water quality as point source and nonpoint source pollution. Generally, agricultural land use is the main provenance of NPS pollution, particularly nitrogen $(\mathrm{N})$ and phosphorus $(\mathrm{P})$, on surface water quality (Hoorman et al. 2008; McCarthy and Johnson 2009). Urban lands are also reported to have considerable effects on surface water quality because of the significant load of contaminants from the point and nonpoint sources (Mallin et al. 2008). The contamination from nutrients, organic matter, and bacteria originates mainly from waste produced by municipal wastewater treatment plants and undefined anthropogenic sources (Glińska-Lewczuk et al. 2016). In this study, the LULC (as determined from the National Land Cover Database 2011 (Homer 2015)), has been divided into eight classes based on their impact on watershed health, where agriculture land uses that have a high impact were classified and rated by a value of (10), while "water" land use class was classified as the lowest rating (1) (Table 4).

\section{Precipitation}

Many studies have assumed that there is a direct relationship between precipitation and increasing pollution levels in surface water. Rapid precipitation can correspond to degradation in water quality of streams and rivers through surface runoff of pollutants (Mallin et al. 2008; Whittemore 2012; Scott and Frost 2017). The high rating of precipitation with watershed susceptibility is associated with rainfall magnitude and intensity due to their impact on sediment and nutrient loading. Therefore, the precipitation (as obtained from the Midwestern Regional Climate Center (MRCC 2016)) was divided into ten classes, where the high rating ( $>75$ in) is represented by a value of (10), while the low precipitation had a value of (1) (Table 4).

\section{Slope}

Slopes that receive rapid precipitation play a significant role in affecting surface water quality (Chang et al. 2008; Qinqin et al. 2015; Meierdiercks et al. 2017). With a steep slope, this factor can increase the flow rate of a water body which can be causing soil erosion and sedimentation and carrying different kinds of pollutants like nutrients, pathogens, and pesticides to nearby rivers (Aksoy and Kavvas 2005; Bracken and Croke 2007). The eroded soil particles can be carried to rivers, which contribute to the level of total suspended solids and a decline in the water quality. Moreover, high slopes have a significant effect on the infiltration rate to groundwater, where the amount of infiltration decreases with the increase in the slope (Fox et al. 1997). Therefore, this study suggested six classes of slope based on their impact on the amount of rainfall that flows over the land surface as overland flow and reaches to surface water or contributes to groundwater by infiltration. Gentle slopes are represented by a value of (1), while steep slopes are classified as having a high value (10) (Table 4), because steep slopes can increase surface runoff that may cause soil erosion and carries different types of pollutants. The average slope for each sub-watershed was determined using a digital elevation model (DEM) has resolution (30 m) obtained from the National Hydrography Dataset (NHD) and slope-calculating algorithms in ArcGIS.

\section{Depth to groundwater}

Surface water and groundwater are connected through a wide range of catchment processes (Dahl et al. 2007; Lehr et al. 2015). Geological factors contribute to groundwater quality, mainly through the influence of chemical processes of waterrock interaction. Therefore, there is a significant impact of rock and soil components on the evolution of water quality by changing the chemical and physical properties of water (Varanka et al. 2014). During rainfall periods, much of the water that flows into nearby rivers and streams comes from shallow pathways through macropore flow in the soil zone, when infiltration to the aquifer is a substantial quantity. The water table will rise to the surface and seep from groundwater into the river, where surface water mixes with groundwater in the hyporheic zone (Lautz and Siegel 2006). The depth to groundwater was classified for eight classes where the shallow groundwater was classified as having a high rating (10), but the deep groundwater was identified as a low rating (1) (Table 4). The depth to groundwater for each watershed was determined by using maps generated by the National Hydrography Dataset (USGS) and calculating the average depth to groundwater for each sub-watershed using GIS tools.

\section{Bedrock type}

Water quality is typically greatly affected by different types of geologic materials, such as sedimentary, igneous, metamorphic rocks, and glacial deposits. Long-term geochemical interaction (rock-water) due to different chemical processes can occur between groundwater and aquifer materials (Oelkers and Schott 2009; Walter et al. 2017). When water flows through fractured rock aquifers (e.g., limestone or dolomite), 
the chemical properties of groundwater can be significantly changed because of the dissolution of some carbonate and evaporite minerals in the aquifer. Therefore, the quality of surface water can be affected by the exchange of water between rivers and shallow aquifers, especially in the alluvial aquifer. Water can seep from a shallow aquifer into the adjacent river and river water flows into the shallow aquifers alternately, depending on the oscillating of water table and river stage. In our study, rock types have been classified for six classes based on their resistance to weathering. The class of metamorphic/igneous rocks was given a low value (1), as this type of rock is normally very hard and resistant to weathering, while limestone was given a high rating (10) (Table 4). The bedrock type for each sub-watershed was determined using the National Hydrography Dataset (USGS) and averaging the values for each bedrock type based on the number of pixels associated with each bedrock type within each subwatershed.

\section{Soil type}

Soil can be a source of soluble materials and suspended sediments (Kerr 1995). In general, sediment is the water pollutant which mostly affects surface water quality biologically, physically, and chemically (Rickson 2014). Bigger, heavier sediments like pebbles and sand settle first while smaller, lighter
Table 4 The relative weights and rating scores of the factors and sub-criteria used for watershed susceptibility assessment

\begin{tabular}{|c|c|c|c|}
\hline Factor & Weighting & Sub-criteria & Rating \\
\hline \multirow[t]{8}{*}{ LULC } & \multirow[t]{8}{*}{0.36} & Agriculture & 10 \\
\hline & & Urban & 9 \\
\hline & & Grassland & 7 \\
\hline & & Wetland & 6 \\
\hline & & Forest & 5 \\
\hline & & Barren land & 4 \\
\hline & & Shrubland & 3 \\
\hline & & Water & 1 \\
\hline \multirow[t]{8}{*}{ Soil type } & \multirow[t]{8}{*}{0.22} & Clay loam & 10 \\
\hline & & Silty loam & 8 \\
\hline & & Silty clay loam & 7 \\
\hline & & Clay & 6 \\
\hline & & Silt & 5 \\
\hline & & Sandy loam & 4 \\
\hline & & Peat & 3 \\
\hline & & Sandy & 2 \\
\hline \multirow[t]{10}{*}{ Average annual precipitation (inch) } & \multirow[t]{10}{*}{0.18} & $>75$ & 10 \\
\hline & & $71-75$ & 9 \\
\hline & & $66-70$ & 8 \\
\hline & & $61-65$ & 7 \\
\hline & & $56-60$ & 6 \\
\hline & & $51-55$ & 5 \\
\hline & & $46-50$ & 4 \\
\hline & & $41-45$ & 3 \\
\hline & & $35-40$ & 2 \\
\hline & & $<35$ & 1 \\
\hline \multirow[t]{6}{*}{ Slope (degree) } & \multirow[t]{6}{*}{0.10} & $>60$ & 10 \\
\hline & & $31-60$ & 8 \\
\hline & & $16-30$ & 6 \\
\hline & & $11-15$ & 4 \\
\hline & & $4-10$ & 2 \\
\hline & & $<3$ & 1 \\
\hline \multirow[t]{8}{*}{ Depth to groundwater (feet) } & \multirow[t]{8}{*}{0.09} & $<5$ & 10 \\
\hline & & $5-10$ & 8 \\
\hline & & $11-15$ & 6 \\
\hline & & $16-20$ & 5 \\
\hline & & $21-25$ & 4 \\
\hline & & $26-50$ & 3 \\
\hline & & $51-100$ & 2 \\
\hline & & $>100$ & 1 \\
\hline \multirow[t]{6}{*}{ Bedrock type (depth $(0-50 \mathrm{ft}))$} & \multirow[t]{6}{*}{0.05} & Limestone & 10 \\
\hline & & Dolomite & 9 \\
\hline & & Shale & 7 \\
\hline & & Claystone & 5 \\
\hline & & Sandstone & 3 \\
\hline & & Metamorphic/igneous & 1 \\
\hline
\end{tabular}


sediment particles like silt and clay can stay for a long time, increasing water turbidity. Furthermore, many types of soluble salts in the soil can affect water quality by increasing electrical conductivity (EC) (Chhabra 1996). A high clay content will increase EC due to the high cation-exchange capacity (CEC) of clay minerals. Soil types have been classified for eight soil classes based on their impact on water quality. The sandy type of soil was given a low value (1), while clay loam was classified and given a value of (10) (Table 4), since this soil type can affect water quality by increasing turbidity and salinity. The soil type for each sub-watershed was determined using the National Hydrography Dataset (USGS) and averaging the values for each soil type based on the number of pixels associated with each soil type within each sub-watershed.

\section{Results and discussion}

The watershed susceptibility assessment method uses some features that have been weighted based on their contribution in surface water contamination and calculates a vulnerability index value for the area under consideration. The vulnerability to pollution is ranked as follows: for values of $70-100$, watershed vulnerability is very high; values of $50-70$ is high vulnerability; values of 30-50 is moderate vulnerability; values of 10-30 are low vulnerability; and values of $0-10$ are very low vulnerability to contamination. To implement the proposed method, six main factors have been identified to evaluate ten sub-watersheds within the ECW. Assessment units ranked between 0 and 1 have low scores - indicating a very low impact on water quality. High scores were assigned as having a very high impact on water quality. Sub-categories were rated between 1 and 10 where 1 refers to very low impacts on water quality while high scores generally were rated as having a very high impact.

The vulnerability evaluation of each watershed was used to create maps showing relative vulnerabilities of sub-watersheds. The map of watershed susceptibility in Fig. 5 shows a remarkable difference between the sub-watersheds in the vulnerability to pollution in the ECW. The upper part of the watershed, represented by Lion Creek and Finley Creek sub-watersheds, has been classified as likely to have very high vulnerability to potential contaminants. Similarly, the subwatersheds Dixon Branch, Mounts Run, and Jackson Run are also identified as highly vulnerable to contamination based on the average value of vulnerability. Thus, around $37.6 \mathrm{~km}^{2}$ $(8 \%)$ of the total area of the ECW was classified as having a very high vulnerability to contamination, and $284.5 \mathrm{~km}^{2}$ $(57 \%)$ as a high vulnerability. The greatest area of contamination vulnerability is located in the north and middle of the study area where agricultural land comprises nearly $85 \%$ of total area within the northern sub-watershed. The low and very low range of vulnerability occupies an area around $73.8 \mathrm{~km}^{2}(14 \%)$ and $7.3 \mathrm{~km}^{2}(1 \%)$, respectively.

The results showed that very high vulnerability zones were located along the Little Eagle Creek, Finley Creek, Dixon Branch, and Mounts Run Creek. Agriculture is the main land use in this part of the study area, so the high vulnerability in this area is partially caused by agricultural runoff. In addition, the soil type could be another factor influencing water quality. Silty clay loam was the most common type of soil around the drainage channels in the northern part of the ECW. The steepest slopes in this part of the study area are also located near riverbanks. Therefore, the slope factor can increase both the surface runoff rate and soil erosion, increasing the delivery of sediments and pollutants to nearby streams (Tedesco et al. 2005). This process probably causes a deterioration of water quality by increasing electrical conductivity due to the solubility of the lime and soils that contain salts. Moreover, the type of bedrock (limestone), which is close to the surface in northern watersheds, can also lead to a declining water quality by increasing the electrical conductivity of groundwater due to the rock-water interaction in the aquifer (Walter et al. 2017). Eventually, this may later influence surface water quality through local exchange between streams and adjacent shallow aquifers (Lautz and Siegel 2006). The electrical conductivity of groundwater ranged between 500 and $1000 \mu \mathrm{s} / \mathrm{cm}$ in many parts of the ECW. It is evident that the high values of salinity which are observed in many study area streams are likely to be a significant indication of surface water-groundwater interaction.

The vulnerability of the watersheds in the southern part of the study area was classified between medium and weak, especially in the adjacent portions of sub-watersheds along School Branch, Eagle Creek at Grande Avenue, and Little Creek at the 30th Street. Bacterial contamination (E. coli) is the main source of degradation in water quality in the southern part of the watershed, where the urban development is the primary land use. The urban surface runoff can carry considerable quantities of contaminants, including major nutrients and bacteria to nearby streams (Tetzlaff et al. 2010; McGrane et al. 2014). The high levels of E. coli that were observed in the study area may explain the negative impact of urban lands on water quality.

\section{Validation and sensitivity analysis of a developed method}

The sensitivity of the new method of calculating vulnerability was evaluated by comparing the vulnerability rating to different water quality parameters. The correlation coefficients between water quality parameters and vulnerability results are shown in Fig. 6. These results show that the relationship between water quality and vulnerability was a significant 
Fig. 5 Watershed susceptibility distribution map of the Eagle Creek Watershed

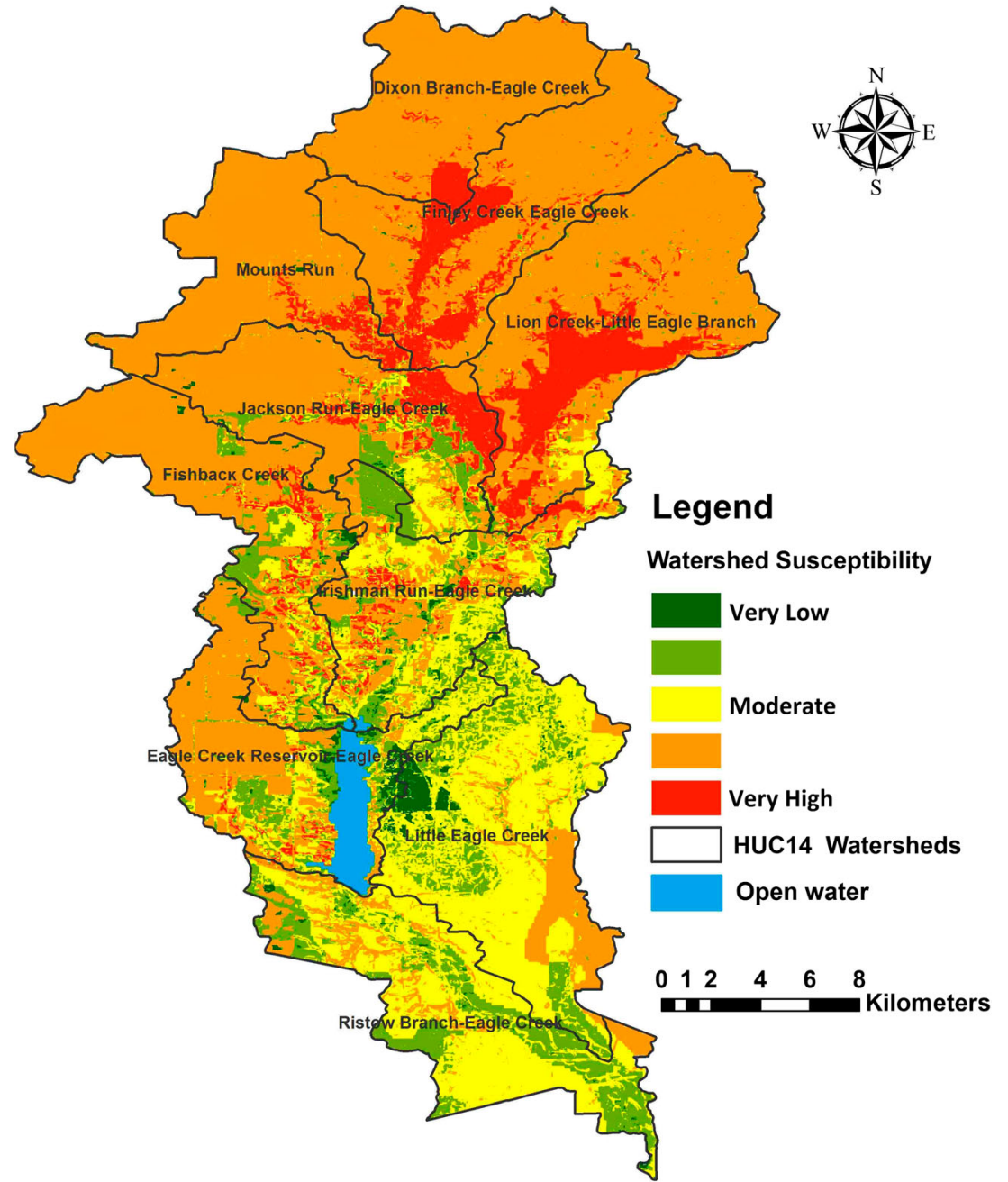

positive correlation with phosphates $\left(r^{2}=0.5, p=0.04\right)$, nitrates $\left(r^{2}=0.4, p=0.03\right)$, and electrical conductivity $\left(r^{2}=0.4\right.$, $p=0.04)$. This indicates the vulnerability would increase with increasing concentrations of these parameters, which have been identified as the main parameters affecting water quality in the study area. The correlation coefficients for dissolved oxygen $\left(r^{2}=0.54, p=0.036\right)$ and $E$. coli $\left(r^{2}=0.6\right.$, $p=0.02$ ) have shown a significant negative relationship with vulnerability. This indicates the potential for water quality degradation as a result of high concentration of bacteria and low levels of dissolved oxygen in the southern part of the study area. Generally, in most watersheds of this study area, the E. coli levels were more than the acceptable limit, but the highest level of these bacteria was observed in the southern region which is dominated by urban development. However, the negative relationship between $E$. coli and vulnerability reflects the impact of land use type on water quality, where E. coli and DO seems to be highly associated with urban land use while $N$ and $P$ associated with agriculture land use.

To assess the water quality of streams and rivers in Eagle Creek Watershed, the water quality index (WQI) (Eq. 8) was applied based on the method which was developed by Cude (2001). The WQI is according to the sub-index measurements of water quality parameters that provide a summary of water quality on a rating scale from (0) very poor-(100) excellent.

$\mathrm{WQI}=\sum_{i=1}^{n} \mathrm{SI}_{i} W_{i}$

where WQI is Water Quality Index, $\mathrm{SI}$ is sub-index $i$, and $W_{i}$ is the weight given to sub-index $i$.

Based on the Water Quality Index results for all eight monitoring stations, it can be concluded that the Eagle Creek Watershed ranged between poor and fair in water quality. All water quality ratings within the northern sub-watershed were poor water quality. This indicator showed fair water quality in Fall Creek and Eagle Creek at Grande Avenue, all of which are located in the southern part of the watershed. In general, E. coli, nitrate, phosphate, and electrical conductivity are the most important parameters that influence surface water quality of these eight sub-watersheds. As can be seen from Fig. 7, as regards the comparison between the WQI and LULC, the surface water 

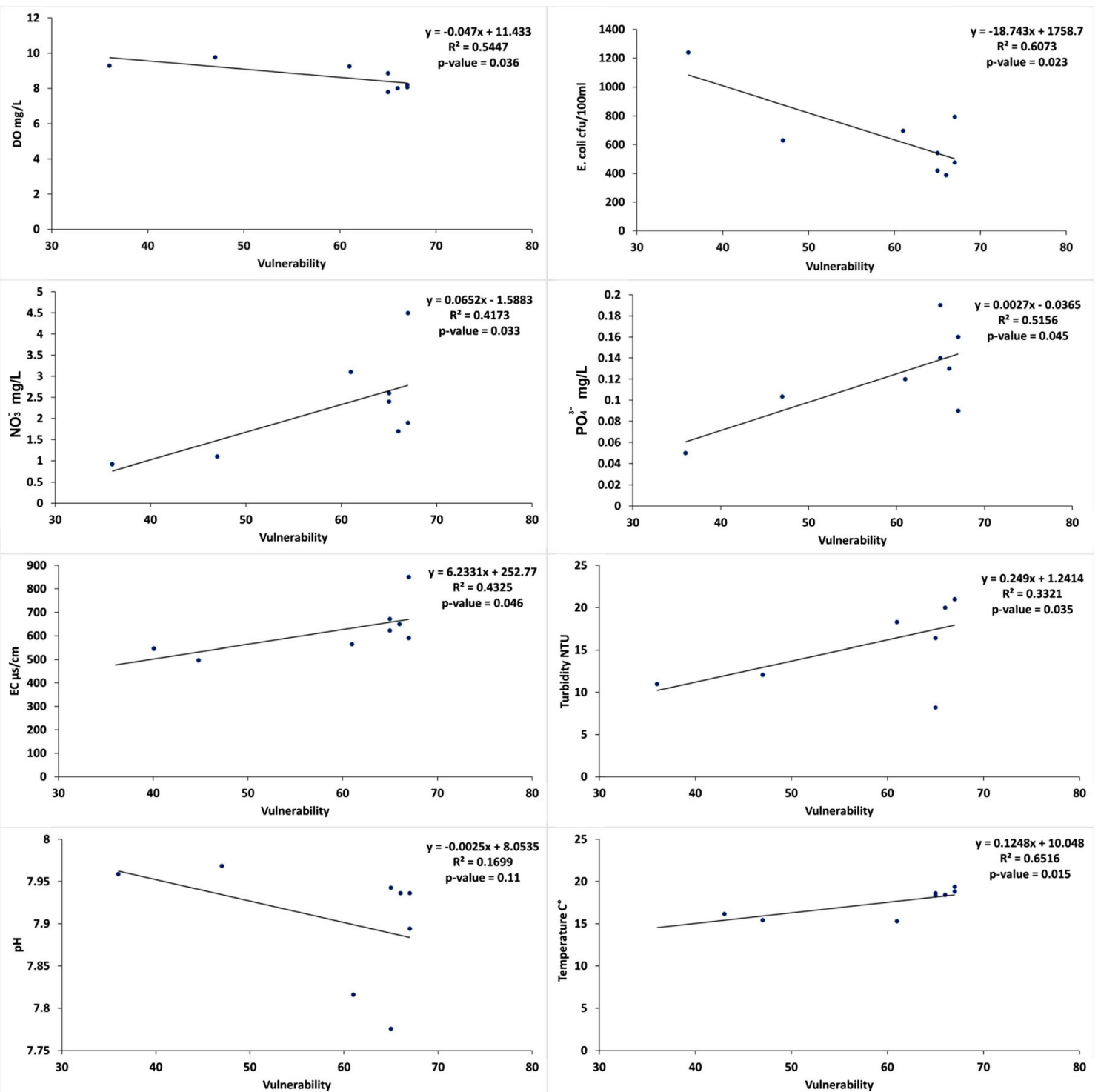

Fig. 6 The relationship between watershed vulnerability and water quality parameters for ECW

quality in the central and northern portion of the study area is classified as poor quality probably because the vast majority of land is agriculture. Conversely, the southern part of the study area shows fair water quality, where the land uses are dominated by urban land. The results of WQI which have been described above were adopted to emphasize the efficiency of the suggested method. As illustrated in Fig. 8, the correlation coefficients between the WQI and watershed vulnerability showed a significant high negative correlation $\left(r^{2}=0.77, p<0.05\right)$. The results of WQI reflect the conditions of water quality in the study area which have been classified as very poor water quality (highly vulnerable to pollution) in the northern sub-watersheds, while it rated as moderate water quality (weak-moderate vulnerability) at the southern sub-watersheds as shown in Fig. 9. These results provide considerable evidence for adopting this method to assess a watershed's susceptibility.
As a comparative study, Eimers et al. (2000) from the USGS developed a method to evaluate the unsaturated zone and watershed characteristics to predict potential contamination for both public groundwater and surface water supplies. This method was applied in North Carolina to evaluate around 11,000 public groundwater supply wells and around 245 public surface water locations. Some watershed characteristics were assigned based on their contribution to the potential that water (with or without pollutants) may reach a surface water supply through overland flow paths or shallow sub-surface flow paths. Factors identified for assessing unsaturated zone vulnerability are vertical hydraulic conductivity, slope, land cover, land use, average annual precipitation, and groundwater contribution. They suggested using statistical analysis of water quality measurements to 


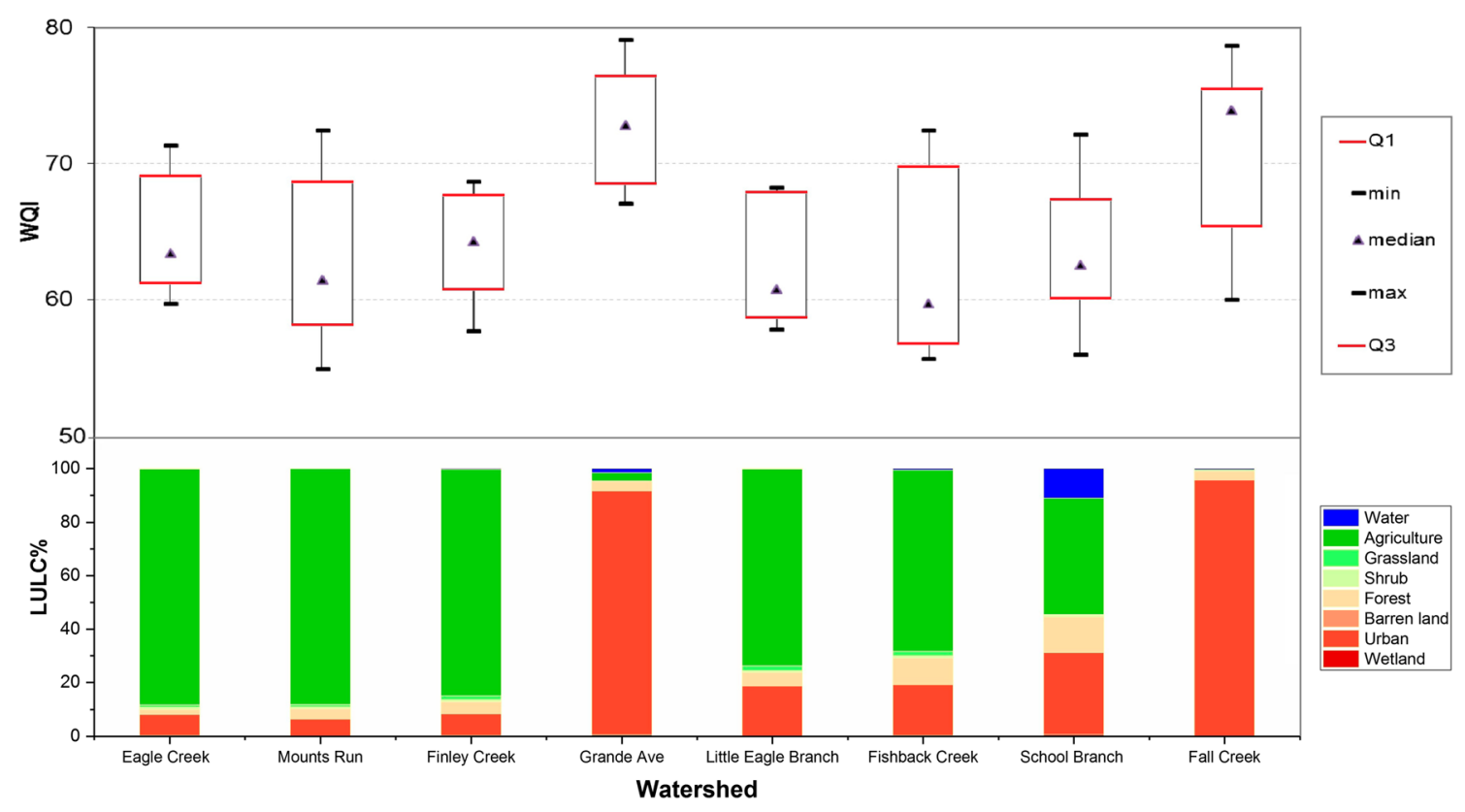

Fig. 7 The relationship between land use/land cover (LULC) types and the WQI in the study area

refine and enhance factor weights and ratings, while in the current study, weight and rating scores were assigned by using the AHP model; additionally, statistical analysis was applied to validate the proposed method. In a recent study conducted by Arriagada et al. (2019) in the Andalién River watershed, located in Mediterranean Chile, they used a new method to evaluate the watershed vulnerability index (WVI) depending on three sub-indices includes environmental fragility, anthropogenic stressors, and natural disturbances. The results of WVI revealed the negative impacts of these stressors on watershed quality. The application of statistical analysis of water quality parameters was presented in the work of Arriagada et al. (2019) and in the current paper, the statistical analysis was applied along with WQI and the vulnerability levels to emphasize the efficiency of the suggested method.

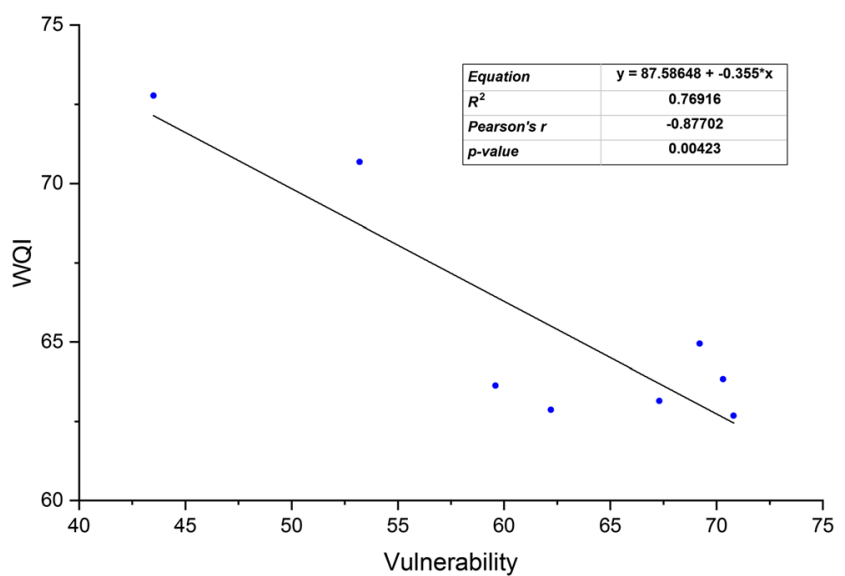

Fig. 8 Comparison showing the relationship between watershed vulnerability and WQI

\section{Conclusions}

In this study, we identified the primary parameters affecting watershed vulnerability and suggested new weighting factors for each parameter using AHP analysis. The proposed method was implemented using suitable six main factors (land uses, soil type, precipitation, slope, depth to groundwater, and bedrock type) to evaluate the watershed susceptibility for $10 \mathrm{sub}$ watersheds within the Eagle Creek Watershed, Indiana. Combination of watershed vulnerability assessment and GIS spatial analysis tools was used to produce the maps that show the susceptible zones for watershed. Based on the results of this method, accounting for around $37.6 \mathrm{~km}^{2}(8 \%)$ of the total area of the watershed was classified as having a very high vulnerability to contamination, and $284.5 \mathrm{~km}^{2}(57 \%)$ as having a high vulnerability. The greatest portion of weakness is located in the middle and north of the study area where agricultural land takes up nearly $85 \%$ of the total area of northern sub-watershed, while the vulnerability for the watersheds in the southern part of the study area was classified between medium and weak. Regression relationships were used to test the effectiveness of this new method. The results demonstrated that the relationship between water quality and vulnerability was a significant positive correlation with phosphates $\left(r^{2}=0.5\right)$, nitrates $\left(r^{2}=0.4\right)$, and electrical conductivity $\left(r^{2}=0.43\right)$. The values of dissolved oxygen $\left(r^{2}=0.54\right)$ and E. coli $\left(r^{2}=0.6\right)$ have shown a significant negative relationship with vulnerability. The correlation between the measured water quality index and the predicted watershed vulnerability for the method showed a high negative correlation $\left(r^{2}=0.77\right)$ between WQI and vulnerability, indicating that the vulnerability predictions are fairly accurate. This method could be used 
Fig. 9 Spatial distribution of Water quality index (WQI) in the ECW

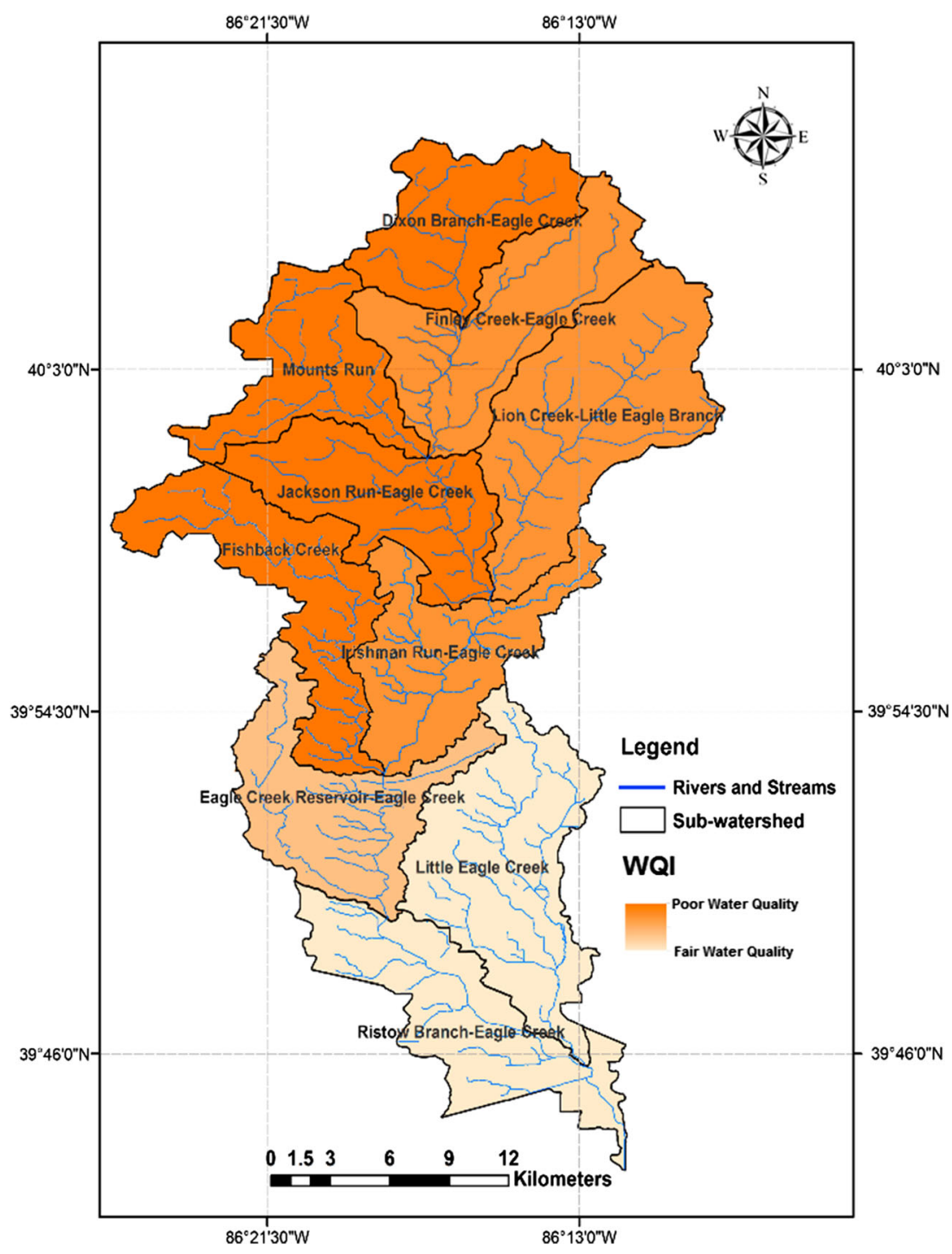

in other watersheds to more accurately assess watershed susceptibility.

Acknowledgments The authors would like to express our appreciation to the Ministry of Higher Education and Scientific Research and the Ministry of Water Resources in Iraq for their support.

Open Access This article is distributed under the terms of the Creative Commons Attribution 4.0 International License (http:// creativecommons.org/licenses/by/4.0/), which permits unrestricted use, distribution, and reproduction in any medium, provided you give appropriate credit to the original author(s) and the source, provide a link to the Creative Commons license, and indicate if changes were made.

\section{References}

Ahn S, Kim S (2017) Assessment of watershed health, vulnerability and resilience for determining protection and restoration priorities. Environ Model Softw. https://doi.org/10.1016/j.envsoft.2017.03.014
Aksoy H, Kavvas ML (2005) A review of hillslope and watershed scale erosion and sediment transport models. CATENA 64(2-3):247-271

Anane M, Bouziri L, Limam A, Jellali S (2012) Ranking suitable sites for irrigation with reclaimed water in the Nabeul-Hammamet region (Tunisia) using GIS and AHP-multicriteria decision analysis. Resour Conserv Recycl 65:36-46. https://doi.org/10.1016/j. resconrec.2012.05.006

Arriagada L, Rojas O, Arumí JL, Munizaga J, Rojas C, Farias L, Vega C (2019) A new method to evaluate the vulnerability of watersheds facing several stressors: a case study in mediterranean Chile. Sci Total Environ 651:1517-1533

Bansal S, James JJ, Sheley RL (2014) The effects of precipitation and soil type on three invasive annual grasses in the western United States. J Arid Environ 104:38-42. https://doi.org/10.1016/j.jaridenv.2014.01.010

Betts A, Gharabaghi B, McBean E (2014) Salt vulnerability assessment methodology for urban streams. J Hydrol 517:877-888. https://doi. org/10.1016/j.jhydrol.2014.06.005

Bracken LJ, Croke J (2007) The concept of hydrological connectivity and its contribution to understanding runoff-dominated geomorphic systems. Hydrol Process 21(13):1749-1763

Chang CL, Kuan WH, Lui PS, Hu CY (2008) Relationship between landscape characteristics and surface water quality. Environ Monit Assess 147(1-3):57-64 
Chhabra R (1996) Soil salinity and water quality. Routledge, Balkema Publishers Vermont, USA

Cruzeiro C, Pardal MÂ, Rocha E, Rocha MJ (2015) Occurrence and seasonal loads of pesticides in surface water and suspended particulate matter from a wetland of worldwide interest - the Ria Formosa Lagoon, Portugal. Environ Monit Assess 187(11). https://doi.org/10. 1007/s10661-015-4824-8

Cude CG (2001) Oregon water quality index: a tool for evaluating water quality management effectiveness. JAWRA37:125-137

Dahl M, Nilsson B, Langhoff J, Refsgaard J (2007) Review of classification systems and new multi-scale typology of groundwater-surface water interaction. J Hydrol 344(1-2):1-16

Daly C (1996) Overview of the PRISM model, PRISM climate mapping program: accessed march 18, 1999, at URL http://www.ocs.orst. edu/prism/ prism_new.Html

Ding J, Jiang Y, Liu Q, Hou Z, Liao J, Fu L, Peng Q (2016) Influences of the land use pattern on water quality in low-order streams of the Dongjiang River basin, China: a multi-scale analysis. Sci Total Environ 551-552:205-216. https://doi.org/10.1016/j.scitotenv. 2016.01.162

Dong Z, Wang Z, Liu D, Li L, Ren C, Tang X, Liu C (2013) Assessment of habitat suitability for waterbirds in the West Songnen Plain, China, using remote sensing and GIS. Ecol Eng 55:94-100. https://doi.org/10.1016/j.ecoleng.2013.02.006

Dupas R, Delmas M, Dorioz J, Garnier J, Moatar F, Gascuel-Odoux C (2015) Assessing the impact of agricultural pressures on $\mathrm{N}$ and $\mathrm{P}$ loads and eutrophication risk. Ecol Indic 48:396-407. https://doi. org/10.1016/j.ecolind.2014.08.007

Eimers JL, Weaver JC, Terziotti S, Midgette RW (2000) Methods of rating unsaturated zone and watershed characteristics of public water supplies in North Carolina. Raleigh: U.S. Dept. of the Interior, U.S. Geological Survey

Fan M, Shibata H (2015) Simulation of watershed hydrology and stream water quality under land use and climate change scenarios in Teshio River watershed, northern Japan. Ecol Indic 50:79-89. https://doi. org/10.1016/j.ecolind.2014.11.003

FAO (2017) Water pollution from agriculture: a global review. Rome, Food and Agriculture Organization of the United Nations (FAO)

Fernández D, Lutz M (2010) Urban flood hazard zoning in Tucumán Province, Argentina, using GIS and multicriteria decision analysis. Eng Geol 111(1-4):90-98

Fournier M, Echeverría-Sáenz S, Mena F, Arias-Andrés M, De la Cruz E, Ruepert C (2017) Risk assessment of agriculture impact on the Frío River watershed and Caño Negro Ramsar wetland, Costa Rica. Environ Sci Pollut Res 25(14):13347-13359

Fox D, Bryan R, Price A (1997) The influence of slope angle on final infiltration rate for interrill conditions. Geoderma 80(1-2):181-194

Furniss MJ, Roby KB, Cenderelli D, Chatel J, Clifton CF, Clingenpeel A, Weinhold M (2013) Assessing the vulnerability of watersheds to climate change: results of national forest watershed vulnerability pilot assessments. https://doi.org/10.2737/pnw-gtr-884

Gamper CD, Thöni M, Weck-Hannemann H (2006) A conceptual approach to the use of cost benefit and multi criteria analysis in natural hazard management. Nat Hazards Earth Syst Sci 6(2):293-302

Glińska-Lewczuk K, Gołaś I, Koc J, Gotkowska-Płachta A, Harnisz M, Rochwerger A (2016) The impact of urban areas on the water quality gradient along a lowland river. Environ Monit Assess 188(11). https://doi.org/10.1007/s10661-016-5638-z

Gray HH, Ault CH, Keller SJ (1987) Bedrock geologic map of Indiana, Indiana Geological Survey, Miscellaneous Map 48, scale 1:500,000

Hall RD (1999) Geology of Indiana, 2nd Edition, IUPUI Department of Geology and Center

Homer CG, Dewitz JA, Yang L, Jin S, Danielson P, Xian G, Coulston J, Herold ND, Wickham JD, Megown K (2015) Completion of the 2011 National Land Cover Database for the conterminous United
States-representing a decade of land cover change information. Photogramm Eng Remote Sens 81(5):345-354

Hoorman J, Hone T, Sudman T, Dirksen T, Iles J, Islam KR (2008) Agricultural impacts on lake and stream water quality in grand Lake St. Marys, Western Ohio. Water Air Soil Pollut 193(1-4): 309-322

Jabbar FK, Grote K (2019) Statistical assessment of nonpoint source pollution in agricultural watersheds in the Lower Grand River watershed, MO, USA. Environ Sci Pollut Res 26(2):1487-1506

Ji X, Xie R, Hao Y, Lu J (2017) Quantitative identification of nitrate pollution sources and uncertainty analysis based on dual isotope approach in an agricultural watershed. Environ Pollut 229:586594. https://doi.org/10.1016/j.envpol.2017.06.100

Kanakoudis V, Tsitsifli S, Papadopoulou A, Cencur Curk B, Karleusa B (2017) Water resources vulnerability assessment in the Adriatic Sea region: the case of Corfu Island. Environ Sci Pollut Res 24(25): 20173-20186

Kerr SJ (1995) Silt, turbidity and suspended sediments in the aquatic environment: an annotated bibliography and literature review. Brockville: Ontario Ministry of Natural Resources, Science and Technology Transfer Unit

Koc-San D, San B, Bakis V, Helvaci M, Eker Z (2013) Multi-criteria decision analysis integrated with GIS and remote sensing for astronomical observatory site selection in Antalya province, Turkey. Adv Space Res 52(1):39-51

Kourgialas NN, Karatzas GP, Koubouris GC (2017) A GIS policy approach for assessing the effect of fertilizers on the quality of drinking and irrigation water and wellhead protection zones (Crete, Greece). J Environ Manag 189:150-159. https://doi.org/10.1016/j.jenvman. 2016.12.038

Lautz LK, Siegel DI (2006) Modeling surface and ground water mixing in the hyporheic zone using MODFLOW and MT3D. Adv Water Resour 29(11):1618-1633

Lehr C, Pöschke F, Lewandowski J, Lischeid G (2015) A novel method to evaluate the effect of a stream restoration on the spatial pattern of hydraulic connection of stream and groundwater. J Hydrol 527:394401. https://doi.org/10.1016/j.jhydrol.2015.04.075

Liu J, Guo L, Luo X, Chen F, Zeng EY (2014) Impact of anthropogenic activities on urban stream water quality: a case study in Guangzhou, China. Environ Sci Pollut Res 21(23):13412-13419

Lopez RD, Nash MS, Heggem DT, Ebert DW (2008) Watershed vulnerability predictions for the Ozarks using landscape models. J Environ Qual 37(5):1769

Mallin MA, Johnson VL, Ensign SH (2008) Comparative impacts of stormwater runoff on water quality of an urban, a suburban, and a rural stream. Environ Monit Assess 159(1-4):475-491

McCarthy KA, Johnson HM (2009) Effect of agricultural practices on hydrology and water chemistry in a small irrigated catchment, Yakima River Basin, Washington. Reston: U.S. Geological Survey

McGrane SJ, Tetzlaff D, Soulsby C (2014) Application of a linear regression model to assess the influence of urbanised areas and grazing pastures on the microbiological quality of rural streams. Environ Monit Assess 186(11):7141-7155

Meierdiercks KL, Kolozsvary MB, Rhoads KP, Golden M, McCloskey NF (2017) The role of land surface versus drainage network characteristics in controlling water quality and quantity in a small urban watershed. Hydrol Process 31(24):4384-4397

Midwestern Regional Climate Center (MRCC) (2016) (1981-2010) Normal annual snowfall-Midwestern States. Retrieved from /cliwatch/annual_snowfall_normals_8110.png

Moeinaddini M, Khorasani N, Danehkar A, Darvishsefat AA, Zienalyan M (2010) Siting MSW landfill using weighted linear combination and analytical hierarchy process (AHP) methodology in GIS environment (case study: Karaj). Waste Manag 30(5):912-920

Mouri G, Takizawa S, Oki T (2011) Spatial and temporal variation in nutrient parameters in stream water in a rural-urban catchment, 
Shikoku, Japan: effects of land cover and human impact. J Environ Manag 92(7):1837-1848

Neupane RP, Kumar S (2015) Estimating the effects of potential climate and land use changes on hydrologic processes of a large agriculture dominated watershed. J Hydrol 529:418-429. https://doi.org/10. 1016/j.jhydrol.2015.07.050

Oelkers EH, Schott J (2009) Thermodynamics and kinetics of water-rock interaction. Chantilly: Mineralogical Society of America

Qinqin L, Qiao C, Jiancai D, Weiping H (2015) The use of simulated rainfall to study the discharge process and the influence factors of urban surface runoff pollution loads. Water Sci Technol 72(3):484-490

Rahman MR, Shi ZH, Chongfa C (2014) Assessing regional environmental quality by integrated use of remote sensing, GIS, and spatial multi-criteria evaluation for prioritization of environmental restoration. Environ Monit Assess 186(11):6993-7009

Rickson R (2014) Can control of soil erosion mitigate water pollution by sediments? Sci Total Environ 468-469:1187-1197

Rowny JG, Stewart JR (2012) Characterization of nonpoint source microbial contamination in an urbanizing watershed serving as a municipal water supply. Water Res 46(18):6143-6153

Saaty TL (1980) The analytic hierarchy process. McGraw-Hill, New York

Saaty TL (1990) An exposition of the AHP in reply to the paper "remarks on the analytic hierarchy process". Manag Sci 36(3):259-268

Saaty TL (2008) 'Decision making with the analytic hierarchy process', Int. J. Services,

Saaty TL, Vargas LG (2001) Models, methods, concepts \& applications of the analytic hierarchy process. Boston: Kluwer Academic Publishers

Sahoo S, Dhar A, Kar A (2016) Environmental vulnerability assessment using Grey analytic hierarchy process based model. Environ Impact Assess Rev 56:145-154. https://doi.org/10.1016/j.eiar.2015.10.002

Scott AB, Frost PC (2017) Monitoring water quality in Toronto's urban stormwater ponds: assessing participation rates and data quality of water sampling by citizen scientists in the FreshWater watch. Sci Total Environ 592:738-744. https://doi.org/10.1016/j.scitotenv. 2017.01.201

Serpa D, Nunes J, Keizer J, Abrantes N (2017) Impacts of climate and land use changes on the water quality of a small Mediterranean catchment with intensive viticulture. Environ Pollut 224:454-465. https://doi.org/10.1016/j.envpol.2017.02.026

Shao H, Sun X, Wang H, Zhang X, Xiang Z, Tan R, Qi J (2016) A method to the impact assessment of the returning grazing land to grassland project on regional eco-environmental vulnerability. Environ Impact Assess Rev 56:155-167. https://doi.org/10.1016/j.eiar.2015.10.006

Shaver RH, Ault CH, Burger AM, Carr DD, Droste JB, Eggert DL, Gray $\mathrm{HH}$ et al (1986) Compendium of rock-unit stratigraphy in Indiana; a revision: Indiana Geological Survey Bulletin, no. 59, 203 p

Simha P, Mutiara ZZ, Gaganis P (2017) Vulnerability assessment of water resources and adaptive management approach for Lesvos Island, Greece. Sustainable Water Resour Manag 3(3):283-295

Siqueira HE, Pissarra TC, Do Valle Junior RF, Fernandes LF, Pacheco FA (2017) A multi criteria analog model for assessing the vulnerability of rural catchments to road spills of hazardous substances. Environ Impact Assess Rev 64:26-36. https://doi.org/10.1016/j.eiar.2017.02.002

Strangway C, Bowman MF, Kirkwood AE (2017) Assessing landscape and contaminant point-sources as spatial determinants of water quality in the Vermilion River system, Ontario, Canada. Environ Sci Pollut Res 24(28):22587-22601. https://doi.org/10.1007/s11356017-9933-1

Tedesco LP, Pascual DL, Shrake LK, Hall RE, Casey LR, Vidon PGF, Hernly FV, Salazar KA, Barr RC, Ulmer J, Pershing D (2005) Eagle Creek Watershed management plan: an integrated approach to improved water quality. Eagle Creek Watershed Alliance, CEES publication 2005-07, IUPUI, Indianapolis, 182p. http://www.cees.iupui.edu

Tetzlaff D, Soulsby C, Birkel C (2010) Hydrological connectivity and microbiological fluxes between landscapes and riverscapes: the importance of seasonality. Hydrol Process 24:1231-1235. https:// doi.org/10.1002/hyp.7680

Tran LT, O'Neill RV, Smith ER (2012) A watershed-based method for environmental vulnerability assessment with a case study of the Mid-Atlantic region. Environ Impact Assess Rev 34:58-64. https://doi.org/10.1016/j.eiar.2011.11.005

U.S. Environmental Protection Agency (2000) State of New Mexico Source water assessment and protection program. State of New Mexico, Environment Department, Drinking Water Bureau, NMED/DWB (Appendix E-WRASTIC index: Watershed vulnerability estimation using WRASTIC by Gallegos, P.E.D., Lowance, P.E.J. \& Thomas, C. (http://www.nmenv.state.nm.us/dwb/ Documents/SWAPP 2000.PDF)

U.S. Environmental Protection Agency (2008) Handbook for developing watershed plans to restore and protect our waters. EPA 841-B-08002, U.S. Environmental Protection Agency, Office of Water, Washington, 400 p. (Accessed 8-22-2014)

U.S. Environmental Protection Agency (2013) National Rivers and Streams Assessment 2008-2009: A Collaborative Survey

U.S. Environmental Protection Agency (2016) National nonpoint source program: A catalyst for water quality improvements. EPA 841-R16-009. U.S. Environmental Protection Agency, Office of Water, Office of Science and Technology, Washington

U.S. Geological Survey (2016) USGS Watershed Boundary Dataset (WBD) overlay map service from The National Map - National Geospatial Data Asset (NGDA) Watershed Boundary Dataset (WBD): USGS National Geospatial Technical Operations Center (NGTOC)

Uyan M (2013) GIS-based solar farms site selection using analytic hierarchy process (AHP) in Karapinar region, Konya/Turkey. Renew Sust Energ Rev 28:11-17. https://doi.org/10.1016/j.rser.2013.07.042

Varanka S, Hjort J, Luoto M (2014) Geomorphological factors predict water quality in boreal rivers. Earth Surf Process Landf 40(15):1989-1999

Walter J, Chesnaux R, Cloutier V, Gaboury D (2017) The influence of water/rock - water/clay interactions and mixing in the salinization processes of groundwater. J Hydrol Reg Stud 13:168-188

Walters SP, Thebo AL, Boehm AB (2011) Impact of urbanization and agriculture on the occurrence of bacterial pathogens and stx genes in coastal waterbodies of central California. Water Res 45(4):1752-1762

Whittemore DO (2012) Potential impacts of stormwater runoff on water quality in urban sand pits and adjacent groundwater1. J Am Water Resour Assoc 48(3):584-602

Wondrade N, Dick B, Tveite H (2013) GIS based mapping of land cover changes utilizing multi-temporal remotely sensed image data in Lake Hawassa Watershed, Ethiopia. Environ Monit Assess 186(3): $1765-1780$

Xiaodan W, Xianghao Z, Pan G (2010) A GIS-based decision support system for regional eco-security assessment and its application on the Tibetan plateau. J Environ Manag 91(10):1981-1990

Ying X, Zeng G, Chen G, Tang L, Wang K, Huang D (2007) Combining AHP with GIS in synthetic evaluation of eco-environment quality - a case study of Hunan Province, China. Ecol Model 209(2-4):97-109

Yu S, Xu Z, Wu W, Zuo D (2016) Effect of land use types on stream water quality under seasonal variation and topographic characteristics in the Wei River basin, China. Ecol Indic 60:202-212. https://doi.org/ 10.1016/j.ecolind.2015.06.029

Zhang W, Huang B (2014) Soil erosion evaluation in a rapidly urbanizing city (Shenzhen, China) and implementation of spatial land-use optimization. Environ Sci Pollut Res 22(6):4475-4490

Zhao J, Lin L, Yang K, Li Q, Qian G (2015) Influences of land use on water quality in a reticular river network area: a case study in Shanghai, China. Landsc Urban Plan 137:20-29. https://doi.org/ 10.1016/j.landurbplan.2014.12.010

Publisher's note Springer Nature remains neutral with regard to jurisdictional claims in published maps and institutional affiliations. 